\title{
Article
}

\section{Workforce nationality composition and workplace flexibility in Britain}

\author{
Whyman, Philip B and Petrescu, Alina \\ Available at http://clok.uclan.ac.uk/11008/ \\ Whyman, Philip B ORCID: 0000-0002-3926-1019 and Petrescu, Alina ORCID: \\ 0000-0002-7459-7714 (2014) Workforce nationality composition and \\ workplace flexibility in Britain. International Journal of Manpower, 35 (6). pp. \\ 776-797. ISSN 0143-7720
}

It is advisable to refer to the publisher's version if you intend to cite from the work. http://dx.doi.org/10.1108/IJM-06-2013-0133

For more information about UCLan's research in this area go to http://www.uclan.ac.uk/researchgroups/ and search for < name of research Group>.

For information about Research generally at UCLan please go to http://www.uclan.ac.uk/research/

All outputs in CLoK are protected by Intellectual Property Rights law, including Copyright law. Copyright, IPR and Moral Rights for the works on this site are retained by the individual authors and/or other copyright owners. Terms and conditions for use of this material are defined in the policies page.

\section{CLoK}

Central Lancashire online Knowledge www.clok.uclan.ac.uk

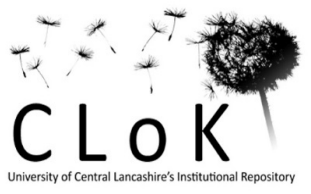


The International Journal of Manpower

Special Issue on Labour market flexibility and spatial mobility

\title{
Workforce nationality composition and workplace flexibility in Britain
}

\author{
Author 1 Name: Professor Philip B. Whyman \\ Department: Lancashire Institute for Economic and Business Research (LIEBR), Lancashire Business School \\ University/Institution: University of Central Lancashire \\ Town/City: Preston, PR1 2HE \\ Country: United Kingdom
}

Author 2 Name: Dr. Alina I. Petrescu

Department: Lancashire Institute for Economic and Business Research (LIEBR), Lancashire Business School University/Institution: University of Central Lancashire

Town/City: Preston, PR1 2HE

Country: United Kingdom

\section{Structured Abstract:}

Purpose - This paper, with an organisational focus, offers a novel examination of the association between workforce nationality composition and workplace flexibility practices (WFPs), an under-researched topic with high potential benefits at microeconomic and macroeconomic level.

Design/methodology/approach - British data is used, as the United Kingdom (UK) has experienced significant immigrant flows and has a relatively high level of labour market flexibility. The Workplace Employee Relations Survey (WERS) 2011, sampling 2,500 British workplaces, offers for the first time data on workforce nationality. Via zero-inflated regressions, the number of non-UK nationals employed in a workplace is assessed against a wide range of numerical, functional and cost WFPs.

Findings - There are significant links between WFPs and the employment of non-UK nationals, and these are distinct for non-UK nationals from the European Economic Area (EEA) when compared to non-UK nationals from outside the EEA. The former are more likely to be in 'good' employment, with job security, working from home, job autonomy and training. Yet, both types of non-UK nationals are more likely to be employed in workplaces making high use of causal contracts. The implications of these results are discussed.

Originality/value - The paper addresses the need to research migration from a relatively new perspective of WFPs while also taking into account the diversity of non-UK nationals. The topic is of importance to organisations, as well as to labour market and migration policymakers. Timely results are of value in view of heightened interest in migration.

Keywords: Workplace flexibility practices, Migration; WERS 2011; United Kingdom; European Economic Area

Acknowledgments:

The authors acknowledge the Department for Business, Innovation and Skills (BIS), the Economic and Social Research Council (ESRC), the Advisory, Conciliation and Arbitration Service (Acas), the UK Commission for Employment and Skills (UKCES) and the National Institute of Economic and Social Research (NIESR) as the originators of the 2011 Workplace Employment Relations Survey data, and the UK Data Service as the distributor of the data. Primary research and analysis was carried out by the WERS Research Team. None of these organisations or people bears any responsibility for the authors' analysis and interpretations of the data. 


\section{Introduction}

The link between workforce nationality composition and workplace flexibility practices (WPFs) has received surprisingly little attention in the literature. Yet, it could be highly significant to business survival and competitiveness at microeconomic and macroeconomic level. In this paper, by using a novel organisational focus on this topic, workforce nationality composition in the United Kingdom (UK) is analysed in terms of the number of migrant workers employed in a workplace, and a distinction is made between migrants from the European Economic Area (EEA) and migrants from outside the EEA [1]. It is proposed that, in a firm, the size of these two groups of migrant workers is associated with the WFPs implemented by the respective firm.

WFPs include a large set of practices allowing organisations and employees to adjust their activities in response to market or other business pressures. Casual contracts, flexitime, or training are some examples of WFPs. Twenty-five numerical, temporal, functional and cost or wage WFPs are assessed in this paper. The implementation of WFPs is analysed in migrant-using workplaces, and in workplaces with an all-British workforce, as well as linked to the size of the migrant workforce in a workplace.

This paper has an organizational focus, investigating the previously under-researched topic of the type of workplace flexibility that migrant-using firms offer to their employees. This topic is important because the willingness of employers to hire immigrants is not homogenous, and, thus, organizational characteristics play a part in the 'pull' factor, encouraging immigration, but also in the productive nature of the use of this additional, migrant labour. However, the employment of migrant labour has usually been analysed from an employee perspective, concerning migrants' individual characteristics such as human capital. In contrast, the novel approach in this paper is to focus on the workplace, bringing to light new research into how migrant-employing firms use their labour force. Thus, it is the 
type of firm that is of interest here, with regard to its WFP mix - such as casual versus permanent contracts - leading to poorer of better quality jobs for migrants, and with direct implications for organizational performance and the efficient use of migrant labour.

Therefore, by taking an organisational focus, the paper highlights the type of organisations employing migrant workers, and can thereby link the use a certain set of WFPs to workforce nationality composition. Significantly, it can identify the degree of flexibility, and, more importantly, the type of flexibility that employers are using, such as whether WFPs are arguably leading to more desirable jobs (if training or job autonomy are used), or to less desirable jobs (if shift patterns can't be changed).

For firms, this may have productivity or performance implications whereas for policymakers, it can determine how migrant workers are being used such as whether they are likely to be over-represented in firms which have more zero-hours contracts. There are also practical implications for the growth potential of the economy, since migrants' skill set and the efficiency of their utilisation by British employers are issues of significance to the British economy. For instance, migrants arriving in the UK from the eight countries which accessed the EU (European Union) in 2004 have been reported to make a positive contribution to UK public finances (Dustman et al. 2010). Equitable concerns have been raised, however, related to the potential exploitation of immigrant workers through the offer of lower wages or casual contracts (Shields and Price, 2003; TUC, 2007). Hence, the employment of migrant labour is worthy of further examination to ensure that the economy is best positioned to utilise this additional labour force. Moreover, the analysis of migrant labour can highlight the effectiveness of visa regulations intended to limit access into the UK to migrants who can best contribute towards reducing skills bottlenecks. Furthermore, the study of the links between migrant labour employment and WFPs can inform policy decisions related to labour market flexibility, as well as employers' provision of WFPs. 
The paper is structured as follows. The next section highlights the topic of this paper as being under-researched, offers some brief theoretical underpinnings, and portrays our research as relevant to the UK, a country with high levels of labour market flexibility where migration issues are highly topical. The following section introduces the data used in this paper, namely the 2011 British Workplace Employee Relations Survey, released in February 2013. The section includes a statistical analysis enabled by this recent data which provides new insights into differences in the use of WFPs between migrant-employing workplaces as compared to all-British workplaces. The same section includes the econometric modelling for analysing the links between migrant employment and WFPs. The results section presents the relationships between the size of the migrant workforce in a workplace and the WFPs used in the respective workplace. The last section concludes and highlights policy implications.

\section{Literature and theory}

\subsection{The relevance of studying workplace flexibility and migrant employment in the UK}

WFPs can be defined as encompassing a large range of practices which facilitate workforce adjustments in terms of the number of employees, temporal deployment, skill composition, job content, or remuneration. A useful classification disaggregates WFPs into numerical or temporal, functional, and cost or wage flexibility (Whyman and Petrescu, 2013). Numerical or temporal WFPs allow the adjustment of the number of workers or of their working time, such as by implementing flexitime or job sharing. Functional WFPs pertain to job content flexibility, for instance by providing job autonomy or employee training. Cost WFPs relate to wage flexibility, such as merit pay or profit-related pay.

The WFPs implemented by a firm can have multiple micro and macro-level benefits that contribute to economic development or recovery from economic crisis. Flexible forms of employment are linked to reductions in labour market rigidities, foreign direct investment, 
modern and competitive workplaces, and beneficial employee outcomes such as improved work-life balance and job satisfaction (Bloom and van Reenen, 2006; CBI, 2010; CIPD, 2012; Origo and Pagani, 2008; Whyman and Baimbridge, 2006; Whyman and Petrescu, 2013).

In the UK and Europe, the incidence of WFPs is increasing (CIPD, 2012; Origo and Pagani, 2008; Treu, 1992). For example, it is estimated that up to two thirds of all firms in the UK make a greater use of WFPs in response to the economic recession (CBI, 2009). The three most widespread WFPs are part-time working ( $88 \%$ of firms), working from home on a regular basis (54\%), and flexitime (50\%). Moreover, the UK has a relatively high level of labour market flexibility (Whyman, 2006), and labour mobility is shown to be an essential part of it (Monastiriodis 2003; Paas et al., 2003).

The UK has experienced significant immigrant flows and increases in population levels in the past decade, particularly following the European Union (EU) enlargement in 2004 [2], and features amongst countries in the EU with largest proportions of labour force from nonEU countries (Eurostat, 2011). The estimated migrant population more than doubled between 1991 and 2008, from 3.2 million to 6.6 million (Oxford Economics, 2009). Moreover, the Population Census 2011 reveals that all regions in England and Wales shows increases in residents born outside the UK, of which 3.8 million arrived in the UK between 2001 and 2011 (ONS, 2012). Among advanced industrial nations, with an immigrant population ranging from $4.4 \%$ in Finland to $26.5 \%$ in Australia, the UK is positioned mid-range at $11.3 \%(\mathrm{OECD}, 2012)$. In 2011, the year of focus in this paper, 7.5 million (13\%) of the usual residents in England and Wales (regional areas accounting for the vast majority of the British population) were born outside the UK (ONS, 2012). Migration plays an important role in UK recruitment too. When vacancies are hard to fill, more than a third $(36 \%)$ of UK employers 
highlight that this is due to skill shortages, and the majority of these employers (51\%) intend to recruit migrant workers (CIPD, 2012).

Sources of migration to the UK include the countries in the EEA as well as outside the EEA, and the most common non-UK countries of birth are India, Poland and Pakistan (ONS, 2012). However, it is important to note that different regulations apply for EEA and non-EEA migrants, with regard to the necessity for work visas and entrance to the UK labour market (UK Border Agency, 2013). The main difference is that non-EEA migrants are subject to a skill-based screening, needing to pass a points-based assessment before being allowed to enter UK employment. This visa policy encourages high-skill migration. In contrast, nationals of EEA countries and Switzerland can enter UK employment without applying for special permission from the main regulatory body, the UK Border Agency [3].

Importantly, there are significant implications to be derived for policy and firm strategy from findings suggesting different uses of WFPs by firms. Or this paper finds that these differences can be linked to the workforce nationality composition, particularly with regard to the presence of EEA and/or non-EEA workers in the firm. For instance, firms with all-British staff tend to use more of the WFPs arguably classified as beneficial to the workers, such as training, job autonomy or working from home; comparatively, they also tend to have a lower use of the WFPs arguably less beneficial to workers such as shift work and zero-hours contracts. Therefore, the study of workforce nationality composition and WFPs merits attention.

The common trend in the academic literature on immigration is to examine the labour market institutions at a macroeconomic level, with specific regard to migrants' skills, unemployment, or migrants' labour-supply effects on natives' jobs (Angrist and Kugler, 2003; Bodvarsson et al., 2008; Hunt, 2004). Indeed, a recent special issue of the International Journal of Manpower (Vol. 34 Issue 2) has been specifically dedicated to the topic of 
immigration and welfare (see Drinkwater and Robinson, 2013). Research focused upon the fiscal impact of immigration addresses also the on-going debate on the costs and benefits accruing to the migrants' country of migration origin and country of destination, or productivity effects such as between foreign-owned and domestic firms (Furchtgott, 2013; Masso et al., 2004; Quispe-Agnoli and Zavodny, 2002; Storesletten, 2000). Studies and population statistics generally find that a highly skilled migrant workforce is desirable, as it does not crowd out natives' employment and adds value to the domestic labour market (Wadhwa et al., 2008; MAC, 2012a). In particular to the UK, there are some recent fiscal arguments in favour of migration. They include positive findings such that migrants have high labour force participation rates and low use of benefits or public services (Dustman et al., 2010).

There is, however, a paucity of microeconomic empirical studies and, in particular, little research focused on workplace aspects of migrant labour. This paper makes a contribution in this area, by examining associations between WFPs and workplace nationality composition. It also seeks to highlight significant macroeconomic competitiveness triggers potentially ensuing from this study. For instance, it may inform economic and migration policymakers on how workplace flexibility can be used as a competitive tool in harvesting benefits from EEA and non-EEA migrants. In this respect, it can be argued that the microeconomic study of WFPs and workforce composition allows firms the hitherto unknown advantage to be more informed about the benefits ensuing from the implementation of WFPs in order to better suit a firms' own migrant workforce composition. For instance, functional flexibility is generally associated with higher skilled employees, and in this paper we find that there is a relationship between firms that pay higher wages and migrant workers with higher skills. Thus, firms may pursue a workplace flexibility strategy that could improve productivity, reduce absenteeism, and increase job satisfaction. At policy level, this paper argues that firms should be 
encouraged to offer non-casual contracts which may suit highly skilled workers better. Similarly, cross-country sharing of information on worker skills and transparency of skills would allow higher skilled employees to benefit more from migration, and would benefit employers too.

Similarly, at the national level, policymakers may benefit from studies of WFPs and workforce composition in order to be better able to strike a favourable balance with regard to appropriate migration legislation, or, put differently, encouraging an appropriate use of a migrant flow in jobs characterised by certain degrees of workplace flexibility that are most likely to lead to an efficient use of this additional workforce. Thus, the results of studies focusing on the link between WFPs and workforce nationality composition can inform the design of migration policy by pin-pointing the way British workplaces tend to make use of the migrant workforce, and, conversely, potentially showcasing migrant workers' expectations and preferences for forms of employment of various levels of flexibility. Therefore, migration policies may target or encourage certain types of migrant labour that suit the flexible needs of employers in British firms.

\subsection{Theoretical underpinnings for the study of workplace flexibility and migrant workers}

The study of workplace flexibility can be based on two theoretical strands of thought. The first, pertaining to the interrelatedness between labour market flexibility and workplace flexibility, argues that labour market flexibility can be measured at both microeconomic and macroeconomic level (see Paas et al., 2003). Studies at the macroeconomic level focus on institutional flexibility which relates to labour legislation, labour policy or trade unions, and wage flexibility, the latter referring to labour market wage adjustments (ibid.). The market can be described as moving towards Pareto efficiency in the allocation of resources, while the term labour market flexibility defines the ease and speed with which market adjustments are 
made to reach equilibrium (Paas et al., 2003). At microeconomic level, studies of labour market flexibility have focused on worker flows between countries, aforementioned productivity effects and assessment of net job creation (or destruction) (Eamets, 2002; Quispe-Agnoli and Zavodny, 2002).

In line with the first strand of thought, this paper contributes to the literature by utilising a disaggregated model of workplace flexibility developed in Whyman and Baimbridge (2006) (see Figure 1). It proposes an empirical analysis of workplace flexibility based on this model that captures the multi-faceted nature of workplace flexibility.

\section{FIGURE 1 NEAR HERE}

The advantage of this approach is to offer a comprehensive way of analysing WFPs. This is especially valuable in view of much of the literature focusing on only one or a few WFPs at a time [4]. In Figure 1, the concept of workplace flexibility is disaggregated into numerical, functional and cost flexibility, with examples of WFPs such as high-performance organisation. With regard to the latter, several WFPs fall into the remit of the area of Human Resource Management (HRM) and have been labelled high-performance workplace practices (HPWPs). These include job autonomy, teamwork, or training. A theoretical consensus has not been reached in the HRM literature with regard to links between HRM practices and organisational performance (Guest, 2011). Yet, the HRM literature advances through empirical studies that appear to indicate HPWPs facilitate superior corporate performance and the creation of a motivated and committed workforce (Glover and Butler, 2012; Petrescu and Simmons, 2008; Stavrou et al., 2010).

The second theoretical underpinning lies in the influential Roy model applied to the study of migration by Borjas (1987) (Roy, 1951). In this approach, skills are unobservable, but individuals with higher skills are assumed to earn higher wages. Moreover, migration decisions made by individuals are assumed to be based on earnings, which, in turn, depend on 
skills that are completely transferrable between the source country and the destination country. Thus, a worker optimises income by migrating if wages are higher in the destination country. The theory predicts that workers with higher skills in the country of origin, and, hence, with higher earning potential, will self-select themselves and migrate. They would take advantage of the opportunity to earn more in the destination country than in their country of origin. This theoretical assumption, emphasising the hypothesis that income optimisation acts as a 'pull' factor for migration, is strong, as there may indeed be a multitude of different reasons underpinning migration. Nevertheless, to the extent that this hypothesis is correct, the higher wage levels found in the UK relative to many EU member states, and most non-EEA nations (OECD, 2012), should act as a 'pull' factor for migration. Also, migrants' high skill levels would be expected to be reflected in the type and quality of employment secured within British workplaces.

\section{Empirical study of WFPs and workforce nationality composition in the UK}

\subsection{Data}

The sixth wave in the British Workplace Employee Relations Survey (WERS) is the WERS 2011 (BIS, Acas and NIESR, 2013). It has nationally representative data on around 2,500 British workplaces employing a minimum of five workers, collected during the economic recession in 2011. Reflecting the heightened interest in analysing UK immigration, and for the first time in the WERS series, the WERS 2011 includes questions on employee nationality. The workplace manager is asked to state the number of non-UK nationals working in the respective workplace, and to distinguish as to whether they were from the EEA or from outside the EEA [5]. Hence, using the WERS 2011 cross-section management questionnaire, the workforce nationality composition can be assessed. 
The WERS 2011 contains a large range of WFPs, enabling this study to analyse twentyfive WFPs. The framework exposed in Figure 1 informs the choice of these WFPs, which are classified into numerical or temporal, functional, and cost or wage WFPs. Basic statistics in Table 1, columns 1 and 2, show various workplace characteristics and the WFPs used by workplaces sampled. For example, three quarters $(76 \%)$ of workplaces are UK owned or controlled, and a third (31\%) are in the public sector. With regard to WFPs, teamwork is the most widespread ( $80 \%$ of workplaces) WFP in Britain, closely followed by employees having the ability to reduce their working hours (77\%), and job autonomy (63\%).

\section{TABLE 1 NEAR HERE}

\subsection{WFPs in migrant-using workplaces in the UK}

Nearly half of the British workplaces sampled in the WERS 2011 employ non-UK nationals, and in nearly one fifth of these the non-UK nationals form more than one-quarter of the workforce. Specifically, data on the employment of non-UK nationals is available on 2,338 workplaces, and half of these (1,123 workplaces or $48 \%$ of the sample) employ nonUK nationals. Additionally, a fifth of migrant-employing workplaces (208 workplaces, or $19 \%$ out of the 1,123 ) has a workforce where at least one-quarter of employees are non-UK nationals (migrants). At national level, out of the 2,338 British workplaces with sampled in the WERS 2011 with data on workforce nationality, eight percent (208 workplaces) have a relatively more diverse composition, since more than one-quarter of their employees are nonUK nationals. These findings are in line with reports portraying the British labour market as flexible, with employers making a relatively large use of migrant workforce (Eurostat, 2011; OECD 2012).

New insights on the use of WFPs in Britain are facilitated by a comparative view between migrant-employing workplaces (Table 1, column 3) versus workplaces employing an all- 
British workforce (Table 1, column 4). This analysis shows that migrant-using workplaces are likely to implement the vast majority of WFPs to a greater extent than all-British workplaces. For instance, $52 \%$ of migrant-using workplaces enable working from home, whereas $38 \%$ of all-British workplaces do. In fact, migrant-using workplaces have some of the highest adoption of WFPs when compared to the national average (Table 1, column 1) and to the all-British counterparts (Table 1, column 4). For instance, the national average for the use of teamwork is $80 \%$, whereas amongst those workplaces employing migrant workers the figure is $86 \%$, and for all-British workplaces, $72 \%$. There are only two exceptions: job autonomy and part-time work. It seems that, instead of using part-time work, migrantemploying workplaces resort to casual forms of contract. They are less likely to have employees on low pay, potentially signalling that migrant workers are relatively high-skill and more likely to hold better paying jobs.

The data used by this study is cross-sectional and, hence, causality cannot be inferred. However, figures in Table 1 imply a direct link between employers making relatively more use of WFPs and a higher likelihood that they employ migrant workers. This finding is revealing with regard to the use of human capital by British workplaces, showing that the employment of migrants is directly linked to a flexible workplace. Consequently, the finding offers support for considering the presence of migrant employees in the workforce to be an indicator of workplace flexibility implemented by a firm. Migration is also associated with the increased flexibility of organisations over and above the simple fact that enhancing the supply of labour will create a looser labour market.

Since the WERS 2011 is cross-sectional, it does not differentiate between firms with only UK staff that may be mainly active in industry sectors generally using fewer WFPs and firms employing migrant workers that may be mainly active in more flexible sectors. Yet, data analysis based on industrial disaggregation, regional disaggregation, or the economic cycle - 
all factors assumed constant for the firms in our data - was considered beyond the scope of this paper's main focus on linking workforce nationality composition and WFPs [6].

\subsection{Econometric model, method and testing}

The model can be formally expressed as:

$$
N_{i}=\propto+\beta X_{i}+\gamma \text { Numerical }_{i}+\text { SFunctional }_{i}+\theta \text { Cost }_{i}+\varepsilon_{i}
$$

where the dependent variable $N$ measures the number of migrant employees in the workplace $i$; $X$ is a vector of workplace characteristics including workplace ownership and workplace size; Numerical, Functional, Cost are vectors of WFPs taken from the data; $\propto$ is the constant term; $\beta, \gamma, \delta$ and $\theta$ are coefficients to be determined; while $\varepsilon$ is the error term.

Equation 1 is used in two econometric analyses of the relationship between workforce national composition and WFPs. In a first analysis, the dependent variable $N_{l}$ measures the number of EEA workers in the workplace, as follows:

$$
N_{1 i}=\propto_{1}+\beta_{1} X_{i}+\gamma_{1} \text { Numerical }_{i}+\delta_{1} \text { Functional }_{i}+\theta_{1} \text { Cost }_{i}+\varepsilon_{1}
$$

In a second, separate analysis, the dependent variable $N_{2}$ measures the number of nonEEA workers in the workplace, as follows:

$$
N_{2 i}=\propto_{2}+\beta_{1} X_{i}+\gamma_{2} \text { Numerical }_{i}+\delta_{2} \text { Functional }_{i}+\theta_{2} \text { Cost }_{i}+\varepsilon_{2}
$$

Table 2 shows that the average British workplace makes higher use of EEA workers (40) than non-EEA workers (17). This finding is supported by migration information on the WERS 2011 sample of total employees. Out of the total workforce surveyed across the 2,500 workplaces sampled in the WERS 2011, six percent are EEA employees and three percent are non-EEA employees. Further analysis of this discrepancy is not pursued here.

\section{TABLE 2 NEAR HERE}

The dependent variables in equations 2 and 3 have two characteristics of high importance to the choice of econometric model: over-dispersion (a high standard deviation when 
compared to their average), and a high number of observations taking the value zero (where workplaces did not employ any migrant workers). Table 2 also shows that there is a high variation in the employment of migrant workers across British workplaces. For the variable measuring the number of EEA workers, the standard deviation is seven times higher than the average. Similarly, for the variable measuring non-EEA workers, the standard deviation is five times higher than the average. Additionally, both variables have a high proportion of zero observations. The number of EEA workers is zero for 1,400 workplaces $(60 \%$ of observations), while the number of non-EEA workers is zero for 1,490 workplaces $(64 \%$ of observations). Due to these characteristics of the dependent variables, zero-inflated regressions are an appropriate estimation technique for Equations 2 and 3. For Equation 2, the appropriate econometric estimation is zero-inflated Poisson regressions, while for Equation 3 it is zero-inflated negative binomial regression.

Despite a high number of independent variables, multicollinearity is not a concern, since Pearson correlations coefficients are of relative low absolute value (Table 3). Moreover, there is no concern for multicollinearity since the Variance Inflation Factor (VIF) test statistic is under 1.5 , and hence it is significantly below the threshold value of 10.0 that would have indicated multicolinearity.

\section{TABLE 3 NEAR HERE}

The finding that Pearson correlations are generally low, with an absolute value below 0.4 , validates the rationale for testing WFPs via a disaggregated model and including a wide range of WFPs without the risk of multicollinearity. In practice, it is shown that workplaces tend to not implement WFPs in a coherent manner, but rather in a fragmented way, whereby there is no pattern of association between numerical, functional or cost WFPs. This comprehensive analysis offers the benefit of highlighting the individual associations between WFPs and workforce nationality composition. 
Further model testing with regard to the appropriate choice of estimation technique is enabled by the Vuong (1989) test statistics (Table 4, last row). These are highly statistically significant and above 1.96, which indicates a preference for a zero-inflated regression over a simple nonzero-inflated regression [7].

\section{TABLE 4 NEAR HERE}

\section{Results}

There are statistically significant relationships between the organisational provision of WFPs and the number of migrant workers employed in the respective workplace. Marginal effects indicate that these links are more significant for EEA workers (Table 4, Model 1) than for non-EEA workers (Table 4, Model 2).

Coefficients are interpreted with regard to the number of migrant workers in the average workplace (Table 2), standing at forty EEA workers in Model 1, respectively seventeen nonEEA workers in Model 2. For example, in Table 4, Model 1, the coefficient of 2.454 for Working from home shows that there is a statistically highly significant relationship between the number of EEA workers and this WFP. Respectively, workplaces implementing Working from home are likely to have a number of EEA employees higher by two EEA employees when compared to workplaces not implementing this WFP; and the size of this coefficient has to be kept in perspective with regard to the forty EEA employees hired by the average British workplace. However, in Model 2, Working from home is not statistically significantly associated with the number of workers from outside the EEA.

Potentially better employment for EEA migrants. EEA migrants are more likely to be employed in workplaces implementing job security, merit pay, training, or working from home (see Table 4). This is an interesting finding, which can also be formulated as an observation that, when compared to non-EEA migrants, EEA migrants are more likely to be found in jobs that could be described as desirable or good. These job qualifiers apply in so far 
as the WFPs available in a job are sought-after by employees. Indeed, the literature suggests that these WFPs are desirable job aspects (CIPD, 2011). For instance, research on the aspects that define a good job emphasises the importance of taking into account a large variety of employee-desirable job factors, most of which can be described as related to WFPs, such as hours of work or job security (Barting et al., 2012; Clark, 1998; Jones et al., 2012; Origo and Pagani, 2008; Petrescu and Simmons, 2008). In fact, in a large-scale study in Britain, job security is found to be a key desirable factor, to the extent that, if job security were the same, differences in job satisfaction would be expected to be eliminated between employees on permanent and non-permanent types of contract (Green and Heywood, 2007).

Results in Table 4 show that, compared to the number of forty EEA migrants hired by the average British workplace, there are likely to be six more EEA workers in workplaces implementing job security, two more EEA workers if implementing Working from home, three more EEA workers if the workplace provides a nursery as part of its family policies, three more EEA workers if pay is contingent on results, one more EEA workers if Training is provided or Teamwork is used, and nearly one fewer employees if offering relatively low pay.

Furthermore, the academic literature often links the prospect of good employment with a highly skilled workforce, while lower skilled employees are more likely to be found on casual contracts, suffering from relatively low levels of job security (Flestead, and Gallie, 2004; Kelliher and Anderson, 2008). Thus, an explanation for the results in Table 4 may be the assertion that EEA migrants are more skilled, since the EEA migrant flow seems to associate with good jobs.

The debate on skilled versus non-skilled migration usually centres on the often selfevident view that skilled migration is preferred by the receiving country, due to raising average skill levels (Hunt, 2002). To this extent, for instance, the UK implements immigration policies intended to select the most skilled applicants (MAC, 2012b). In this 
context, this paper's results with regard to EEA-workers being potentially highly-skilled, may be interpreted as showing that the unrestrictive nature of the UK immigration policy for EEA workers need not be of concern - the EEA migrant flow seems to be highly skilled, despite the lack of skill-based restrictions imposed on their entry to the UK labour market. This is a surprising finding in view of the expectation that unrestricted labour movement for EEA migrants to the UK would lead to a mixed migrant workforce, as opposed to a predominantly highly-skilled one. It is a reassuring finding with regard to UK potentially benefiting from an already positively selected highly-skilled EEA migration, which is in line with theoretical predictions of the Roy model (Roy, 1951). This finding offers specific support to the unrestrictive migration policy that UK implemented after the 1995 EU enlargement. Moreover, in the light of results supporting the assumption that migrants may be self-selected as high-skilled workers, this paper signals support for the maintenance of similar, unrestrictive UK labour market migration policies, for instance in view of Romanian and Bulgarian migrants who will not face any more restrictions from January 2014.

Jobs held by EEA migrants may be characterised as good due to EEA migrant employment being associated with certain sought-after WFPs, but also in a relative perspective, when compared to the WFPs that non-EEA are likely to have in their jobs. There are much fewer statistically significant associations between non-EEA workers' employment and WFPs (see Table 4, Model 2). When applying the aforementioned assumptions in terms of qualifying certain WFPs as desirable, results show that non-EEA workers are most likely associated with different WFPs than EEA workers, and these WFPs may be found in less desirable jobs. Results show that, when compared to seventeen non-EEA workers found in the average workplace in Britain, a workplace is likely to have two fewer non-EEA workers if implementing Changing shift patterns, one fewer non-EEA employees if Training is provided, twelve more non-EEA employees if using agency workers, and two more non-EEA 
workers if the workplace has relatively low pay. By association, relatively poor working conditions could reflect a low skill base for non-EEA migrants, lower human capital transferability (such as language barriers), lower opportunities to for pre-migration job searches, or discriminatory tastes by employers in Britain. If non-EEA migrants had a comparatively lower skill base, this would then call into question the effectiveness of governmental migration policy aimed at restricting non-EEA migration to highly-skilled migrants.

These results may imply that there are marketed differences between the jobs held by EEA and non-EEA workers. There is an association between a better, 'high road' type of employment and EEA workers, across all categories of numerical, temporal, functional and cost WFPs, whereas non-EEA workers are not likely to have similar job opportunities [8]. These results cannot prove or disprove equity concerns with regard to the employment of migrants compared to native workers. However, the differences between WFPs on offer to EEA and non-EEA workers would merit further investigation as to the reasons behind the relatively more desirable associations between EEA migrant employment and WFPs. Similarly, another potentially interesting area of further study would be to examine whether (and how) differences in workforce nationality composition may associate with organisational outcomes (i.e. corporate performance, employee motivation and/or productivity).

Casualised employment for migrant workers. The assertion that these jobs are better needs to be exercised with caution, due to two main aspects. Firstly, some of the strongest associations between WFPs and the size of the migrant workforce are for WFPs used in casual contracts. EEA employment is associated with fixed term work and agency work; also, non-EEA employment is associated with agency work and has the highest coefficient (12) in Table 4. Or, the literature on casual employment finds that forms of casual contract are not 
desirable for employees (see Green et al., 2010). Secondly, the employees' side of the story has not been heard. Hence this study qualifies WFPs and jobs as 'desirable' based on whether in other studies these WFPs are positively perceived by employees. Further study into on how WFPs associate with superior versus inferior jobs is needed, in order to investigate whether migrants' tastes for WFPs validate these assumptions. In particular, further investigation could offer insights into overall job quality ratings when contracts are casualised, to ascertain whether potentially more desirable WFPs available to employees (such as working from home) may mitigate some of the less desirable facets of casual contracts (such as low job security).

Some of the results related to workplace characteristics and migrant employment are as follows. In contrast to foreign owned workplaces, British owned workplaces are less likely to use EEA workers. This is an intuitive finding, since foreign owned workplaces would be more likely to hire workers from abroad.

\section{Conclusions and policy implications}

This paper, with an organisational focus, addresses a gap in the literature with regard to the study of associations between workplace flexibility practices (WFPs) and workforce national composition. The merits of this research lie in uncovering previously unknown avenues for economic development at the level of the firm and at the general economic level. Benefits that may ensue from optimising the profile of workplace flexibility to suit various immigrant flows include increased business competitiveness, employee morale and macroeconomic growth.

The value-added of this research lies in offering a novel WFPs perspective into the employment of immigrants from the European Economic Area (EEA) and from outside the EEA. The UK is a good case study, due to its large migrant base, high labour market 
flexibility and widespread use of WFPs in British workplaces. Data is taken from the 2011 Workplace Employee Relations Survey (WERS) which is the sixth and most recent wave in WERS series. The WERS 2011 is a nationally representative dataset covering employment practices in around 2,500 British workplaces. For the first time in the WERS series, the WERS 2011 contains questions on the national composition of the workforce. This enables the empirical analysis of links between WFPs and the number of migrants employed in a workplace.

Findings show that there are significant links between WFPs and the employment of nonUK nationals, and these are distinct for non-UK nationals from the EEA when compared to non-UK nationals from outside the EEA. Significantly, the former are more likely to be employed where workplaces provide desirable WFPs such as job security, working from home, job autonomy, merit pay, or flexitime. EEA employees are less likely to be found in workplaces with relatively low wages. This implies that EEA workers are likely to be skilled workers, able to secure good employment in terms of job security and pay. Hence, results may support the view that British immigration schemes for EEA workers need not be restrictive.

In contrast, the presence of migrants from outside the EEA in a workforce is not linked to the same WFPs that were statistically significant in the analysis of the EEA migrant employment. In effect, immigrants from outside the EEA are less likely to be employed in workplaces offering training, and more likely to work in organisations where pay levels are relatively low.

There are several limitations in this study which call for further data availability and further research. The WERS 2011 is cross-sectional, hence causality cannot be inferred. Longitudinal data may showcase the way in which the provision of WFPs is linked with changes in the migrant workforce composition after the introduction of the respective WFPs, 
or to various economic periods such as recession or boom. Moreover, data on migrant characteristics would be useful, such as age, skill level, whether they are first-time or return migrants, whether they are migrants with the same or a different employer, or migrant country of origin.

Findings are relevant to business practitioners and policymakers by showcasing the potential of WFPs and immigration policy to attract, deter or match the skill level and employment abilities of migrant flows. This paper highlights new insights as to the use of WFPs by firms with various workforce nationality compositions. The implications for policymakers and firms relate to the potential to inform strategic decisions related to firms' use of labour and to migration policy. For firms, this is reflected in the heightened ability to choose which WFPs to implement in order to match the flexibility of jobs on offer to the type - preferences, skills, expectations of flexible work - of workers employed. At national level, information on flexible workplaces and their needs and use of migrant workers would help to support and develop migration policies that encourage the 'right' type of migrant flow to suit the flexible needs of employers in Britain. Benefits ensuing from the aforementioned match would include higher worker and firm productivity and performance, lower labour turnover, or lower absenteeism; at national level, this could help to increase both migrant and native employment, thereby saving costs in unemployment benefit or due to social unrest. Therefore, the study of workforce nationality composition and WFPs merits increased attention at micro and macroeconomic level.

Poignantly, there are benefits associated with enhancing a country's ability to adjust its labour market to make best use of potentially available migrant human capital. Thus, findings are useful to scrutinising the relevance of the British-offering of WFPs to migrants. This paper makes a dual contribution here, firstly with regard to disaggregating WFPs into numerical, functional and cost WFPs, and demonstrating that the type of flexibility most 
likely to link with the employment of migrants are numerical and temporal, specifically agency workers and fixed-term contracts. Secondly, although data on migrants' characteristics are not available, the migrant flow was treated heterogeneously according to whether employees are from the EEA or outside the EEA, and both types of migrants are most highly associated to causal contracts. Hence, this research calls for enhanced support to be given to organisations with regard to their offering non-casual employment too, to potentially highly skilled migrants who may otherwise be on casual contracts, suffering due to hiring discrimination, or less transferrable skills or qualifications. Similarly, it suggests the policy need for an increase in the transparency and applicability across countries of the information related a worker's skills and labour market experience.

Lastly, the analysis of WFPs in Britain finds that migrant-using firms are more flexible than all-British firms. When employers make relatively more use of WFPs, then they are also more likely to employ migrant workers. This finding is revealing with regard to the use of human capital by firms, showing that the employment of migrants is directly linked to a flexible workplace. Consequently, this finding offers support for considering the presence of migrant employees in the workforce to be an indicator of workplace flexibility implemented in a firm. Therefore, the composition of a workforce is proposed to be a useful indicator of both microeconomic and macroeconomic labour flexibility.

\section{Notes}

1. The European Economic Area (EEA) comprises the 27 member states of the European Union, plus Iceland, Liechtenstein, Norway. While Switzerland is not in the EEA, Swiss nationals have the same rights as the EEA nationals. The agreement on the EEA entered into force on 1 January 1994 (EEA Agreement, 2011).

2. The countries which joined the EU in 2004 were Cyprus, the Czech Republic, Estonia, Hungary, Latvia, Lithuania, Malta, Poland, Slovakia and Slovenia. Their citizens only had immediate access to the labour markets of two EU countries, the UK and Ireland, whereas other EU countries imposed transitional access restrictions. 
3. Regulations of this type have been continually enforced throughout the existence of the EEA. Further regulatory detail tends to be complex and its coverage and relevance falls outside the remit of this study.

4. For example, Gariety and Shaffer (2007) only analyse working from home; Bradley et al. (2012) focus on temporary working; or Grzywacz et al. (2008) focus on schedule flexibility.

5. A workplace is described as the organisation of work comprising the activities of a single employer carried out at one or more premises. The questions asked are: "How many of the non-UK nationals working here are nationals from the European Economic Area?", and, respectively "How many of the non-UK nationals working here are from outside the European Economic Area?". The data used in this paper did not allow the analysis of individual employee information, such as individual levels of education or skill.

6. Nevertheless, data analysis did include a dummy variable for the manufacturing industry to control for the use of WFPs across sectors. Detailed industrial and regional workplace indicators were not released as part of the publicly-available version of the data used in this paper.

7. Zero-inflated regressions assume that there are two simultaneous processes generating the zero observations for the number of migrant workers. Thus, whilst it may be a coincidence that workplaces do not employ any migrant workers, it might equally arise from several employment or workplace characteristics. Zero-inflated regressions account for both options. Full model specifications for the zeroinflated regressions in Table 4 are available from the authors upon request, whereas, due to space constraints, only marginal effects are reported in the paper. Alternative modelling also confirms the stability of the results. For instance, a probit model based on dependent variables generated as dummies for non-zero values, gives similar results. Also, when independent variables are entered one at a time, the results do not change. An alternative model converting the dependent variables to show the percent of migrant employees in the workforce was not implemented. This is due to the added statistical complexity that would have been introduced by expressing the dependent variables (which are over-dispersed and take the value zero for sixty percent of observations) as a percent, thus limiting the range of their values to between $0 \%$ and $100 \%$. Thus, in this paper the dependent variables measure the absolute size of the migrant workforce, and estimations include controls for workplace size. Moreover, logarithmic transformations of the dependent variables were not suitable either, due to the high number of zero observations. Nevertheless, numerous estimations with slightly modified sets of workplace 
characteristics and / or selection of independent variables have been trialled, and they indicate that the research results presented here are consistent and robust.

8. The 'high' versus 'low road' is a dichotomy proposed and examined by Michie and Sheehan-Quinn (2001).

\section{References}

Agrist, J. D. and Kugler, A. D. (2003), "Protective or counter-productive? Labour market institutions and the effect of immigration on EU natives", The Economic Journal, Vol. 113 No. 488, pp. F302F331.

Barting, B., Fehr, E. and Schmidt, K. M. (2012), "Screening, competition, and job design: Economic origins of good jobs", American Economic Review, Vol. 102 No. 2, pp. 834-864.

BIS, Acas and NIESR [Department for Business, Innovation and Skills, Advisory, Conciliation and Arbitration Service and National Institute of Economic and Social Research] (2013), Workplace Employee Relations Survey, 2011 [computer file]. Colchester, Essex: UK Data Archive [distributor], February, SN: 7226.

Bloom, N. and Van Reenen, J. (2006), "Management practices, work-life balance and productivity: A review of some recent evidence", Oxford Review of Economic Policy, Vol. 22 No. 4, pp. 457-482.

Bodvarsson, Ö. B., Van den Berg, H. F. and Lewer, J. J. (2008), "Measuring immigration's effects on labour demand: A reexamination of the Mariel Boatlift', Labour Economics, Vol. 15 No. 4, pp. 560574.Borjas, G. J. (1987), "Self-selection and the earnings of immigrants", American Economic Review, American Economic Association, Vol. 77 No. 4, pp. 531-53.

Bradley, S., Green, C. and Leeves, G. (2012), "Employment protection, threat and incentive effects on worker absence", British Journal of Industrial Relations, DOI: 10.1111/j.1467-8543.2012.00916.x

CBI [Confederation of British Industry] (2009), Employment Trends 2009: Work Patterns in the Recession, Report, June, London, UK.

CBI [Confederation of British Industry] (2010), Making Britain the Place to Work: An Employment Agenda for the New Government, Report, June, London, UK.

CIPD [Chartered Institute of Personnel and Development] (2012), Flexible Working and Its Uptake, Survey Report, May, London, UK.

CIPD [Chartered Institute of Personnel and Development] (2012), Labour Market Outlook, Autumn, London, UK.

Clark, A. E. (1998), "Measures of job satisfaction: What makes a good job? Evidence from OECD Countries", OECD Labour Market and Social Policy Occasional Papers, No. 34, OECD Publishing. DOI: http://dx.doi.org/10.1787/670570634774

Drinkwater, S. and Robinson, C. (2013), "Welfare participation by immigrants in the UK", International Journal of Manpower, Vol. 34 No. 2, pp. 100-112.

Dustman, C., Frattini, T. and Halls, C. (2010), "Assessing the fiscal costs and benefits of A8 migration to the UK", Fiscal Studies, Vol. 31 No. 1, pp. 1-41.

Eamets, R. (2002), "Estonian labour market flexibility in the context of EU accession", Conference proceedings in Effect of Accession to the European Union on the Economic Policy of Estonia, Berlin, Tallinn, pp. 54-64.

EEA [Economic European Area] Agreement (2011), Agreement on the European Economic Area Updated, 15 November, available at: http://secretariat.efta.int/ /media/Documents/legal- 
texts/eea/the-eea-agreement/Main $\% 20 \mathrm{Text} \% 20 \mathrm{of} \% 20$ the $\% 20$ Agreement/EEAagreement.pdf (accessed 05 June 2013).

Eurostat (2011), Labor Force Survey. Brussels: The European Commission.

Felstead. A. and Gallie, D. (2004), "For better or worse? Non-standard jobs and high involvement work systems", International Journal of Human Resource Management, Vol. 15 No. 7, pp. 12931316.

Furchtgott-Roth, D. (2013), The economic benefits of migration. Issue Brief No. 18, available at http://www.manhattan-institute.org/html/ib 18.htm\#.UbBiLKlwbcs (accessed 20 May 2013).

Gariety, B. S. and Shaffer, S. (2007), "Wage differentials associated with working at home", Monthly Labor Review, Vol. 130 March pp. 61-67.

Green, C. and Heywood, J. S. (2007), "Are flexible contracts bad for workers? Evidence from job satisfaction data", Lancaster University Management School, Working Paper.

Green, C., Kler, P. and Leeves, G. (2010), "Flexible contract workers in inferior jobs: Reappraising the evidence", British Journal of Industrial Relations, Vol. 48 No. 3, pp. 605-629.

Glover, L. and Butler, P. (2012), "High-performance work systems, partnership and working lives", Human Resource Management Journal, Vol. 22 No. 2, pp. 199-215.

Guest, D. (2011), "Human resource management and performance: still searching for some answers", Human Resource Management Journal, Vol. 21 No. 1, pp. 3-13.

Grzywacz, J. G., Carslon, D. S. and Shulkin, S. (2008), "Schedule flexibility and stress: Linking formal flexible arrangements and perceived flexibility to employee health", Community, Work and Family, Vol. 11 No. 2, pp. 199 - 214.

Hunt, J. (2004), "Are migrants more skilled than non-migrants? Repeat, return, and same-employer migrants", Canadian Journal of Economics, Vol. 37 No. 4, pp. 830-849.

Jones, W., Haslam, R. and Haslam, C. (2012), "How do people differentiate between jobs; and how do they define a good job?", Work, Vol. 41 February, pp. 818-821.

Kelliher, C. and Anderson, D. (2008), "For better or for worse? An analysis of how flexible working practices influence employees' perceptions of job quality", International Journal of Human Resource Management, Vol. 19 No. 3, pp. 419-431.

MAC [Migration Advisory Committee] (2012a), Limits on Migration. February, Report, available at: http://www.ukba.homeoffice.gov.uk/sitecontent/documents/aboutus/workingwithus/mac/limit-tier2settle/ (accessed 05 June 2013).

MAC [Migration Advisory Committee] (2012b), Analysis of the Impacts of Migration. January, Report, available at:

http://www.ukba.homeoffice.gov.uk/aboutus/workingwithus/indbodies/mac/reports-publications/ (accessed 05 June 2013).

Masso, J., Eamets, R. and Philips, K. (2004), "The impact of firm demographics on productivity growth", University of Tartu, Faculty of Economics and Business Administration Working Paper Series, Issue 25, pp. 33-44.

Michie, J. and Sheehan-Quinn, M. (2001), "Labour market flexibility, human resource management and corporate performance", British Journal of Management, Vol. 12 No. 4, pp. 287-306.

Monastiriotis, V. (2003), "A panel of regional indicators of labour market flexibility: The UK, 19791998", New Directions in Labour Market Flexibility Research, 26th November, London, UK.

ONS [Office for National Statistics] (2012), International Migrants in England and Wales 2011, December, London, UK.

Origo, F. and Pagani, L. (2008), "Workplace flexibility and job satisfaction: Some evidence from Europe", International Journal of Manpower, Vol. 29 No. 6, pp. 539-566. 
Oxford Economics (2009), "Regional economic performance: A migration perspective", Economics Paper No. 4, Department of Communities and Local Government, London, UK.

OECD [Organization for Economic Cooperation and Development] (2012), OECD Factbook 20112012: Immigrant Population, available at: http://dx.doi.org/10.1787/factbook-2011-en (accessed 05 June 2013).

Paas, T., Eamets, R., Masso, J. and Rõõm, M. (2003), "Labour market flexibility and migration in the Baltic states: Macro evidences", University of Tartu, Faculty of Economics and Business Administration Working Paper Series, Issue 16, pp. 4-101.

Petrescu, A. I., and Simmons, R. (2008), "Human resource management practices and workers' job satisfaction", International Journal of Manpower Special Issue: Subjective Well Being and the Labour Market, Vol. 29 No. 7, pp. 651-667.

Quispe-Agnoli, M. and Zavodny, M. (2002), "The effect of immigration on output mix, capital and productivity", Federal Reserve Bank of Atlanta, Economic Review, First Quarter.

Roy, A. D. (1951), "Some thoughts on the distribution of earnings", Oxford Economic Papers, Vol. 3 No. 2, pp. 135-146.

UK Border Agency (2013), Working in the UK, available at http://www.ukba.homeoffice.gov.uk/visas-immigration/working/ (accessed 18 May 2013).

Shields, M. and Price, S. W. (2003), The Labour Market Outcomes and Psychological Well-Being of Ethnic Minority Migrants in Britain, Report, Home Office, London, UK.

Stavrou, E. T., Brewster, C. and Charalambous, C. (2010), "Human resource management and firm performance in Europe through the lens of business systems: best fit, best practice or both?", International Journal of Human Resource Management, Vol. 21 No. 7, pp. 933-962.

Treu, T. (1992), "Labour flexibility in Europe", International Labour Review, Vol. 131, No. 4-5, pp. 497-513.

Storesletten, K. (2000), "Sustaining fiscal policy through immigration", Journal of Political Economy, Vol. 108 No. 2, pp. 300-324.

TUC [Trades Union Congress] (2007), The Economics of Migration: Managing the impacts, June, available at http://www.tuc.org.uk/international/tuc-13542-f0.cfm\#_edn73 (accessed 06 June 2013).

Vuong, Q. H. (1989), "Likelihood ratio tests for model selection and non-nested hypotheses", Econometrica, Vol. 57 No. 2, pp. 307-333.

Wadhwa, V., Saxenjan, A., Rissing, B. A. and Gereffi, G. (2008), "Skilled immigration and economic growth", Applied Research in Economic Development, Vol. 5 No. 1, pp. 6-14.

Whyman, P. B. (2006), Third Way Economics, Palgrave, London, UK.

Whyman, P. B. and Baimbridge, M. (2006), "Labour market flexibility and foreign direct investment", Employment Relations, Occasional Paper URN 06 / 1797, Department of Trade and Industry, London, UK.

Whyman, P. B. and Petrescu, A. I. (2013), "Partnership, flexible working practices and the realisation of mutual gains: evidence from the British WERS 2004 dataset", International Journal of Human Resource Management, Special Issue: Partnership, Collaboration and Mutual Gains: an International Perspective, pp. 1-23 DOI.org/10.1080/09585192.2012.751439. 


\section{Tables and Figures}

Figure 1: Theoretical view of labour market flexibility / workplace flexibility practices

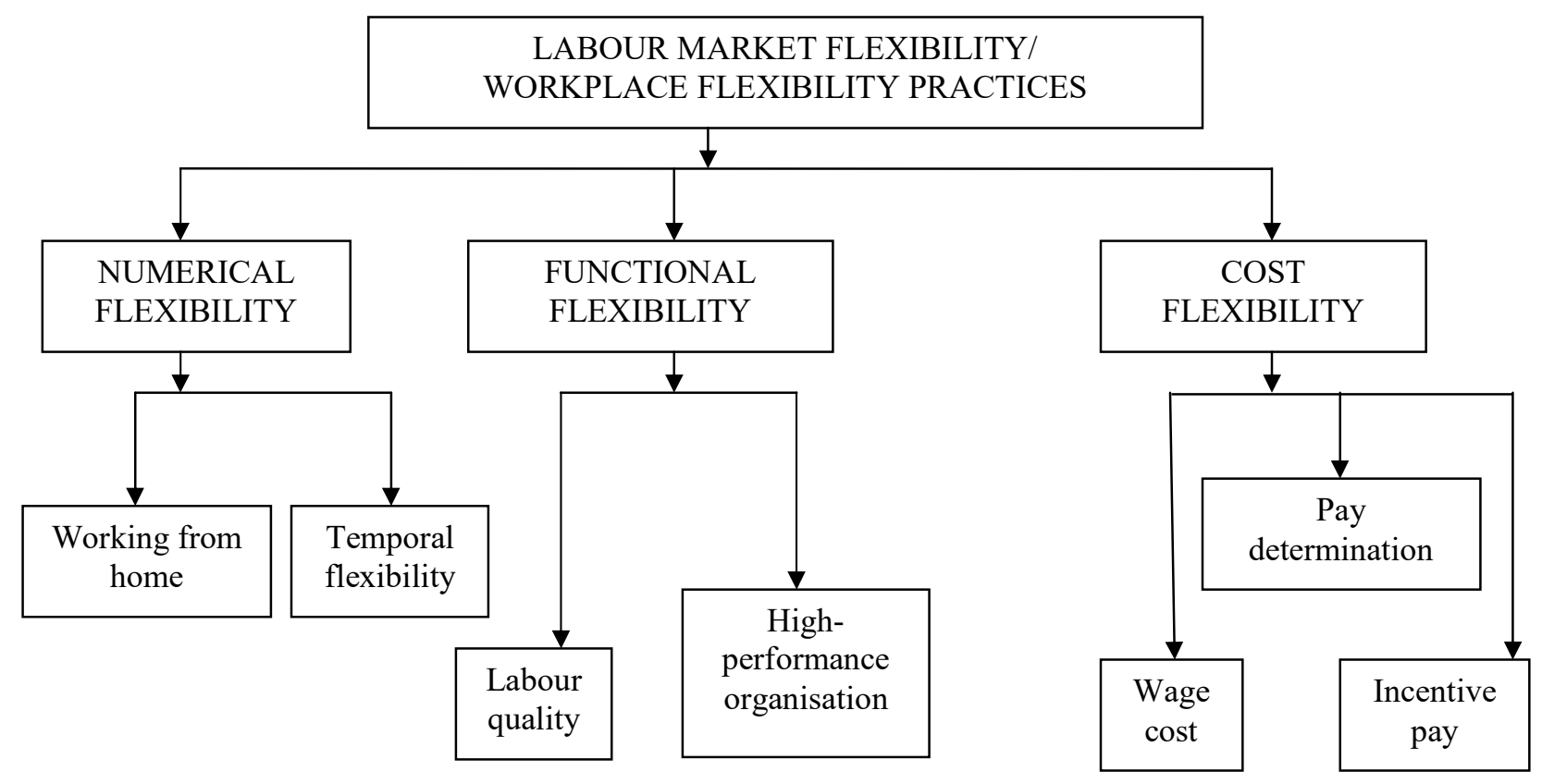

Source: Adapted from Whyman and Baimbridge (2006).

Note: The figure indicates a limited range of workplace flexibility practices that are shown as examples of numerical, functional and cost flexibility. The data analysis in this paper uses a wider range of practices than shown in the figure. 
Table 1: The use of workplace flexibility practices (WFPs) in British workplaces

\begin{tabular}{|c|c|c|c|c|}
\hline & All workpla & $\begin{array}{l}(2) \\
\text { S.D. }\end{array}$ & $\begin{array}{c}\text { Workplaces with } \\
\text { migrant employees in } \\
\text { the workforce } \\
\text { (3) } \\
\text { Avg. }\end{array}$ & $\begin{array}{c}\text { Workplaces with } \\
\text { an all-British } \\
\text { workforce } \\
\text { (4) } \\
\text { Avg. }\end{array}$ \\
\hline \multicolumn{5}{|l|}{ Workplace Flexibility Practices (WFPs) } \\
\hline \multicolumn{5}{|l|}{ Numerical / Temporal WFPs } \\
\hline Working from home & 0.47 & 0.50 & 0.52 & 0.38 \\
\hline Flexitime & 0.48 & 0.50 & 0.49 & 0.42 \\
\hline Job sharing & 0.43 & 0.49 & 0.46 & 0.34 \\
\hline Changing shift pattern & 0.62 & 0.49 & 0.66 & 0.52 \\
\hline Compressed hours & 0.30 & 0.46 & 0.33 & 0.22 \\
\hline Reduce working hours & 0.77 & 0.42 & 0.83 & 0.67 \\
\hline Term time working & 0.36 & 0.48 & 0.37 & 0.29 \\
\hline Family policies: nursery & 0.09 & 0.29 & 0.12 & 0.05 \\
\hline Family policies: subsidies & 0.52 & 0.50 & 0.60 & 0.40 \\
\hline $\begin{array}{l}\text { Family policies: financial help with } \\
\text { care for older adults }\end{array}$ & 0.01 & 0.10 & 0.01 & 0.01 \\
\hline $\begin{array}{l}\text { Family policies: leave to care for } \\
\text { older adults }\end{array}$ & 0.17 & 0.38 & 0.18 & 0.12 \\
\hline Time arrangements: shift working & 0.53 & 0.50 & 0.64 & 0.37 \\
\hline Time arrangements: annualised & 0.18 & 0.39 & 0.23 & 0.11 \\
\hline Time arrangements: zero-hours & 0.18 & 0.38 & 0.25 & 0.09 \\
\hline Internal labour markets present & 0.31 & 0.46 & 0.33 & 0.26 \\
\hline Proportion of part-time employees & 0.27 & 0.26 & 0.24 & 0.31 \\
\hline Proportion of agency workers & 0.03 & 0.08 & 0.04 & 0.01 \\
\hline Proportion of fixed term employees & 0.07 & 0.18 & 0.08 & 0.07 \\
\hline \multicolumn{5}{|l|}{ Functional / High performance WFPs } \\
\hline Job autonomy & 0.63 & 0.48 & 0.60 & 0.68 \\
\hline Training (for all staff in past year) & 0.36 & 0.48 & 0.34 & 0.39 \\
\hline $\begin{array}{l}\text { Teamwork: More than } 40 \text { of } \\
\text { employees work in teams }\end{array}$ & 0.80 & 0.40 & 0.86 & 0.72 \\
\hline Job security $^{\wedge \wedge}$ & 0.10 & 0.30 & 0.07 & 0.11 \\
\hline \multicolumn{5}{|l|}{ Cost WFPs } \\
\hline Profit-related payments & 0.26 & 0.44 & 0.31 & 0.22 \\
\hline Merit pay or payment by results & 0.43 & 0.49 & 0.48 & 0.36 \\
\hline $\begin{array}{l}\text { Proportion of employees on low } \\
\text { pay }^{\wedge}\end{array}$ & 0.25 & 0.33 & 0.24 & 0.28 \\
\hline \multicolumn{5}{|l|}{ Workplace Characteristics } \\
\hline UK owned/controlled workplace & 0.76 & 0.43 & 0.70 & 0.87 \\
\hline Public sector workplace & 0.31 & 0.46 & 0.23 & 0.33 \\
\hline Single independent workplace & 0.26 & 0.44 & 0.24 & 0.32 \\
\hline Manufacturing industry & 0.10 & 0.30 & 0.13 & 0.08 \\
\hline Workplace size (employee headcount) & 450 employees & 1214 & 629 employees & 122 employees \\
\hline Workplace age: up to 9 years & 0.18 & 0.38 & 0.19 & 0.18 \\
\hline Number of observations (workplaces) & 2,338 & & 1,123 & 1,215 \\
\hline
\end{tabular}

Source: WERS 2011.

Notes: ${ }^{\wedge}$ Workplaces have a minimum of 5 employees and a maximum of 20,746 employees. Avg. $=$ Average. S.D. = Standard Deviation. The minimum value of WFPs variables is 0 for all WFPs, and the maximum value is 1 for all variables except the proportion of agency workers (maximum here is 0.95 ). Standard deviation is not shown for columns (3) and (4).

${ }^{\wedge}$ Measuring job security is based on the WERS 2011 question answered by the manager to confirm the presence of a policy of guaranteed job security or no-compulsory redundancies for non-managerial staff.

$\wedge^{\wedge \wedge}$ In 2011, the hourly National Minimum Wage (NMW) in the UK was $£ 6.08$ for employees 21 years old or over, $£ 4.98$ for employees 18 to 20 years old, $£ 3.68$ for employees under 18 years old and $£ 2.60$ for apprentices. Hourly wage information in the WERS 2011 is grouped into six categories: below NMW, above NMW to $£ 7.50, £ 7.51$ to $£ 10.00, £ 10.01$ to $£ 13.00, £ 13.01$ to 18.00 , and above $£ 18.01$. The WFP used in this paper, measures the proportion of employees in the workplace who earn under $£ 7.51$ per hour, respectively in the lowest two wage categories. 
Table 2. Descriptive statistics for the workforce nationality composition in British workplaces

Observations Avg $\quad$ S.D. $\quad$ Min $\quad$ Max

\begin{tabular}{lccccc}
\hline $\begin{array}{l}\text { Number of EEA employees in the } \\
\text { workplace }\end{array}$ & 2,342 & 40 & 280 & 0 & 5,819 \\
$\begin{array}{l}\text { Number of non-EEA employees in } \\
\text { the workplace }\end{array}$ & 2,354 & 17 & 93 & 0 & 1,939 \\
\hline
\end{tabular}

Notes: Avg. $=$ Average. S.D. $=$ Standard Deviation. Min $=$ Minimum value. Max $=$ Maximum value. 
Table 3. Pearson correlation coefficients for workplace flexibility practices (WFPs)

\begin{tabular}{|c|c|c|c|c|c|c|c|c|c|c|c|c|c|c|c|c|c|c|c|c|c|c|c|c|c|}
\hline & 1 & 2 & 3 & 4 & 5 & 6 & 7 & 8 & 9 & 10 & 11 & 12 & 13 & 14 & 15 & 16 & 17 & 18 & 19 & 20 & 21 & 22 & 23 & 24 & 25 \\
\hline \multicolumn{26}{|l|}{$\begin{array}{l}\text { Numerical and } \\
\text { temporal WFPs }\end{array}$} \\
\hline 1 Working from home & 1 & & & & & & & & & & & & & & & & & & & & & & & & \\
\hline 2 Flexitime & 0.35 & 1 & & & & & & & & & & & & & & & & & & & & & & & \\
\hline 3 Job sharing & 0.27 & 0.24 & 1 & & & & & & & & & & & & & & & & & & & & & & \\
\hline 4 Changing shift pattern & 0.13 & 0.14 & 0.18 & 1 & & & & & & & & & & & & & & & & & & & & & \\
\hline 5 Compressed hours & 0.13 & 0.16 & 0.23 & 0.26 & 1 & & & & & & & & & & & & & & & & & & & & \\
\hline 6 Reduce working hours & 0.26 & 0.20 & 0.30 & 0.36 & 0.22 & 1 & & & & & & & & & & & & & & & & & & & \\
\hline 7 Term time working & 0.15 & 0.18 & 0.31 & 0.17 & 0.17 & 0.23 & 1 & & & & & & & & & & & & & & & & & & \\
\hline 8 Family policies: nursery & 0.04 & 0.07 & 0.13 & 0.06 & 0.04 & 0.06 & 0.18 & 1 & & & & & & & & & & & & & & & & & \\
\hline 9 Family policies: subsidies & 0.27 & 0.15 & 0.31 & 0.16 & 0.21 & 0.29 & 0.13 & 0.13 & 1 & & & & & & & & & & & & & & & & \\
\hline $\begin{array}{l}10 \text { Family policies: financial help } \\
\text { with care for older adults }\end{array}$ & 0.03 & 0.03 & 0.06 & 0.05 & -0.01 & 0.05 & 0.06 & 0.16 & 0.10 & 1 & & & & & & & & & & & & & & & \\
\hline $\begin{array}{l}11 \text { Family policies: leave to care } \\
\text { for older adults }\end{array}$ & 0.08 & 0.05 & 0.19 & 0.11 & 0.13 & 0.17 & 0.14 & 0.12 & 0.20 & 0.15 & 1 & & & & & & & & & & & & & & \\
\hline $\begin{array}{l}12 \text { Time arrangements: shift } \\
\text { working }\end{array}$ & -0.07 & 0.04 & 0.15 & 0.29 & 0.19 & 0.18 & 0.08 & 0.12 & 0.11 & 0.00 & 0.10 & 1 & & & & & & & & & & & & & \\
\hline 13 Time arrangements: annualis & 0.12 & 0.09 & 0.20 & 0.12 & 0.11 & 0.09 & 0.20 & 0.15 & 0.11 & 0.00 & 0.12 & 0.15 & 1 & & & & & & & & & & & & \\
\hline $\begin{array}{l}14 \text { Time arrangements: zero- } \\
\text { hours }\end{array}$ & 0.09 & 0.08 & 0.15 & 0.11 & 0.09 & 0.11 & 0.16 & 0.13 & 0.05 & 0.01 & 0.04 & 0.12 & 0.25 & 1 & & & & & & & & & & & \\
\hline 15 Internal labour markets present & 0.09 & 0.04 & 0.08 & 0.05 & 0.02 & 0.09 & 0.01 & -0.03 & 0.14 & -0.02 & 0.04 & 0.06 & 0.06 & -0.02 & 1 & & & & & & & & & & \\
\hline $\begin{array}{l}16 \text { Proportion of part-time } \\
\text { employees }\end{array}$ & -0.23 & -0.08 & -0.06 & 0.09 & -0.01 & 0.00 & 0.16 & 0.06 & -0.19 & -0.02 & 0.00 & 0.08 & -0.03 & 0.15 & -0.11 & 1 & & & & & & & & & \\
\hline 17 Proportion of agency workers & 0.08 & 0.00 & 0.05 & 0.06 & 0.06 & 0.07 & -0.03 & 0.00 & 0.13 & 0.03 & 0.04 & 0.11 & 0.08 & -0.02 & 0.16 & -0.20 & 1 & & & & & & & & \\
\hline $\begin{array}{l}18 \text { Proportion of fixed term } \\
\text { employees }\end{array}$ & -0.01 & 0.01 & -0.02 & 0.03 & 0.02 & -0.04 & 0.03 & 0.08 & -0.09 & -0.01 & -0.03 & 0.01 & -0.02 & 0.06 & -0.04 & 0.13 & -0.06 & 1 & & & & & & & \\
\hline \multicolumn{26}{|l|}{$\begin{array}{l}\text { Functional and high- } \\
\text { performance WFPs }\end{array}$} \\
\hline 19 Job autonomy & 0.09 & 0.09 & 0.02 & 0.01 & 0.05 & 0.03 & 0.08 & 0.06 & -0.03 & 0.03 & 0.00 & -0.12 & 0.00 & 0.00 & -0.08 & 0.03 & -0.10 & 0.08 & 1 & & & & & & \\
\hline $\begin{array}{l}20 \text { Training (for all staff in past } \\
\text { year) }\end{array}$ & -0.03 & -0.02 & 0.00 & 0.07 & 0.04 & 0.09 & 0.03 & 0.00 & 0.03 & 0.00 & 0.09 & 0.09 & 0.03 & 0.04 & -0.02 & 0.02 & 0.01 & -0.01 & 0.03 & 1 & & & & & \\
\hline $\begin{array}{l}21 \text { Teamwork: More than } 40 \text { of } \\
\text { employees work in teams }\end{array}$ & 0.19 & 0.10 & 0.22 & 0.16 & 0.12 & 0.17 & 0.10 & 0.08 & 0.26 & 0.01 & 0.11 & 0.14 & 0.10 & 0.07 & 0.12 & -0.12 & 0.09 & 0.00 & -0.01 & 0.06 & 1 & & & & \\
\hline 22 Job security & 0.01 & 0.03 & 0.04 & 0.04 & 0.06 & 0.02 & 0.02 & -0.01 & 0.01 & 0.03 & 0.10 & 0.06 & 0.05 & 0.00 & 0.04 & -0.02 & 0.01 & -0.02 & 0.04 & 0.05 & 0.02 & 1 & & & \\
\hline \multicolumn{26}{|l|}{ Cost or wage WFPs } \\
\hline 23 Profit-related payments & 0.11 & 0.05 & 0.01 & 0.05 & 0.02 & 0.10 & -0.02 & -0.04 & 0.15 & 0.02 & 0.01 & 0.06 & 0.02 & 0.02 & 0.08 & -0.10 & 0.03 & -0.04 & -0.02 & 0.06 & 0.07 & 0.02 & 1 & & \\
\hline $\begin{array}{l}24 \text { Merit pay or payment by } \\
\text { results }\end{array}$ & 0.14 & 0.03 & 0.07 & 0.04 & 0.01 & 0.10 & -0.04 & -0.01 & 0.18 & 0.02 & 0.07 & -0.03 & 0.02 & 0.00 & 0.12 & -0.17 & 0.07 & -0.04 & 0.00 & 0.01 & 0.13 & -0.04 & 0.21 & 1 & \\
\hline $\begin{array}{l}25 \text { Proportion of employees on } \\
\text { low pay }\end{array}$ & -0.42 & -0.21 & -0.21 & 0.07 & -0.03 & -0.06 & -0.03 & 0.02 & -0.25 & -0.02 & -0.04 & 0.22 & -0.12 & 0.05 & -0.11 & 0.55 & -0.15 & 0.11 & -0.08 & 0.03 & -0.16 & -0.01 & -0.06 & -0.13 & 1 \\
\hline
\end{tabular}

Notes: Observations are for around 2,000 British workplaces. 
Table 4. Relationship between workplace flexibility practices and the number of non-UK nationals employed in a workplace - Marginal effects from zero-inflated regressions

\begin{tabular}{|c|c|c|}
\hline & $\begin{array}{c}\text { Number of employees } \\
\text { from the Economic } \\
\text { European Area } \\
\text { (Model 1) }\end{array}$ & $\begin{array}{l}\text { Number of employees } \\
\text { from outside the } \\
\text { Economic European Area } \\
\text { (Model 2) }\end{array}$ \\
\hline \multicolumn{3}{|l|}{ Workplace Flexibility Practices (WFPs) } \\
\hline \multicolumn{3}{|l|}{ Numerical / Temporal WFPs } \\
\hline Working from home & $2.454 * * *$ & 0.261 \\
\hline Flexitime & $1.605 * * *$ & -0.360 \\
\hline Job sharing & $1.246 * * *$ & $2.381 * * *$ \\
\hline Changing shift pattern & $1.170 * * *$ & $-1.822 * *$ \\
\hline Compressed hours & $-0.653 * * *$ & -0.688 \\
\hline Reduce working hours & $-2.082 * * *$ & 1.245 \\
\hline Term time working & $-1.017 * * *$ & 0.107 \\
\hline Family policies: nursery & $3.794 * * *$ & 1.722 \\
\hline Family policies: subsidies & $2.782 * * *$ & 0.761 \\
\hline $\begin{array}{l}\text { Family policies: financial help with care for } \\
\text { older adults }\end{array}$ & $-0.921 * * *$ & 0.414 \\
\hline $\begin{array}{l}\text { Family policies: leave to care for older } \\
\text { adults }\end{array}$ & $-3.281 * * *$ & 0.684 \\
\hline Time arrangements: shift working & $6.301 * * *$ & $1.962 * * *$ \\
\hline Time arrangements: annualis & $-0.156 * * *$ & 1.743 \\
\hline Time arrangements: zero-hours & $1.042 * * *$ & -0.554 \\
\hline Internal labour markets present & $0.651 * * *$ & 0.650 \\
\hline Proportion of part-time employees ${ }^{\wedge}$ & $0.611 * * *$ & 1.689 \\
\hline Proportion of agency workers^ ${ }^{\wedge}$ & $6.634 * * *$ & $12.269 * * *$ \\
\hline Proportion of fixed term employees $\wedge$ & $7.432 * * *$ & 2.044 \\
\hline \multicolumn{3}{|l|}{ Functional / High performance WFPs } \\
\hline Job autonomy & $1.079 * * *$ & -0.541 \\
\hline Training (for all staff in past year) & $0.953 * * *$ & $-1.188 *$ \\
\hline $\begin{array}{l}\text { Teamwork: More than } 40 \text { of employees } \\
\text { work in teams }\end{array}$ & $-0.810 * * *$ & 0.491 \\
\hline Job security & $5.588 * * *$ & -1.319 \\
\hline \multicolumn{3}{|l|}{ Cost WFPs } \\
\hline Profit-related payments & $-1.542 * * *$ & -0.288 \\
\hline Merit pay or payment by results & $3.180 * * *$ & 0.679 \\
\hline Proportion of employees on low pay ${ }^{\wedge}$ & $-0.647 * * *$ & $2.481 * *$ \\
\hline \multicolumn{3}{|l|}{ Workplace Characteristics } \\
\hline UK owned/controlled workplace & $-4.756 * * *$ & -1.177 \\
\hline Public sector workplace & -1.432 & -2.275 \\
\hline Single independent workplace & $-3.487 * * *$ & 0.478 \\
\hline Manufacturing industry & $2.818 * * *$ & $-2.961 * * *$ \\
\hline Workplace size (employee headcount $)^{\wedge}$ & $0.005 * * *$ & $0.005 * * *$ \\
\hline Workplace age: up to 9 years & $0.955 * * *$ & -0.934 \\
\hline Number of observations & 1,497 & 1,498 \\
\hline Vuong Test-Statistic & $5.75 * * *$ & $6.85 * * *$ \\
\hline
\end{tabular}

